\title{
APARTMENT SEWA SMART LIVING DI JATINEGARA
}

\author{
Kevin Fernando ${ }^{1)}$, Martin Halim ${ }^{2)}$ \\ 1) Program Studi S1 Arsitektur, Fakultas Teknik, Universitas Tarumanagara, kendo_fernando23@yahoo.co.id \\ 2) Program Studi S1 Arsitektur, Fakultas Teknik, Universitas Tarumanagara, martinhalim90@gmail.com
}

\begin{abstract}
Abstrak
Penelitian bertujuan untuk mempelajari tentang perilaku dan kebutuhan Generasi Milenial atau generasi $Y$ yang merupakan generasi yang lahir antara tahun 1981-1994. Sifat dan perilaku Generasi Milenial terbentuk dari berkembangnya ilmu teknologi dan informasi yang digunakannya selama masa hidupnya. Generasi Milenial yang saat ini sedang berada di usia produktif dimana generasi Milenial sudah berkeluarga maupun baru berencana untuk berkeluarga sehingga membutuhkan tempat tinggal. Maka perlu dibuat hunian yang Smart sesuai dengan generasi Milenial yang dekat dengan teknologi dan lebih memilih hal yang simpel dan efisien. Maka dari itu perlu dibuat Apartment smart living yang dapat mengatur hunian mereka menggunakan teknologi dan penggunaan perabotan multifungsi yang membuat efisiensi penggunaan ruang. Metode yang digunakan dalam penelitian ini adalah metode penelitian kualitatif yang terdiri dari tahap pengumpulan data, pengolahan data, pembahasan, dan kesimpulan. Pengumpulan data dilakukan dengan cara observasi atau tinjauan langsung ke lapangan dan studi dokumen. Dari hasil data tersebut, lokasi yang dipilih adalah di daerah Jakarta Timur karena memiliki jumlah Generasi Milenial terbanyak di Jakarta. Generasi ini dapat membawa perubahan terhadap dunia dan juga terhadap perubahan pada bangunan. Maka dari itu penelitian ini diharapkan dapat memberikan rancangan apartment sewa smart living yang dapat memenuhi kebutuhan generasi Milenial.
\end{abstract}

Kata kunci: Arsitektur; Generasi Milenial; Multifungsi; Smart Living; Teknologi

\begin{abstract}
This research is to learn about the behavior and needs of the Millennial generation or generation $Y$ that born between 1981-1994. The character and behavior of the Millennial Generation is formed from the development of technology and information that they use during their lifetime. The Millennial generation curently in a productive age where the Millennials are already married and or planning to have a family so they need a place to live. So it is necessary to make a Smart housing that suitable for Millennial Generation that familiar with technology and prefers things that are simple and efficient. So it is necessary to build a Smart living Apartment that can control their house using technology and the use of multifunctional furniture that makes efficient use of space. The method used in this study is a qualitative research method consisting of the stages of data collection, data processing, discussion, and conclusions. Data collection is done by direct observation or review into the field and study of documents. From the results of these data, the chosen location is in the East Jakarta area because it has the highest number of Millennials in Jakarta. This generation can bring changes to the world and also changes in the building. Therefore this study is expected to provide smart living rent apartment designs that can fulfill the needs of the Millennial generation.
\end{abstract}

Keywords: Architecture; Millennial Generation; Multifunction; Smart Living; Technology

\section{PENDAHULUAN}

Generasi Milenial atau generasi Y merupakan generasi yang lahir antara tahun 1981-1994 yang sekarang ini berada di usia produktif dan memiliki jumlah terbesar secara global saat ini. Terbentuknya generasi Milenial tidak terlepas dari peran generasi generasi sebelumnya. Generasi Milenial terbentuk dari berkembangnya ilmu teknologi dan informasi dan generasi 
Milenial berinteraksi dengan teknologi secara intens dan menggunakannya secara terintegrasi selama masa hidupnya yang mempengaruhi cara pandang generasi Milenial terhadap dunia dengan membuka peluang untuk berinteraksi dengan kejadian atau orang di belahan dunia lain.

Hal tersebut membuat generasi Milenial menjadi generasi yang Smart karena dapat menggunakan teknologi yang ada untuk memberikan kemudahan dalam melakukan pekerjaan dan aktivitas mereka. Maka perlu dibuat hunian yang Smart sesuai dengan generasi Milenial yang dekat dengan teknologi dan lebih memilih hal yang simpel dan efisien. Maka dari itu perlu dibuat Apartment smart living yang dapat mengatur hunian mereka menggunakan teknologi dan penggunaan perabotan multifungsi yang membuat efisiensi penggunaan ruang.

\section{KAJIAN LITERATUR}

Milenial dikenal juga sebagai generasi $\mathrm{Y}$, adalah kelompok demografi setelah generasi $\mathrm{X}$. generasi ini merupakan generasi yang lahir antara tahun 1981 - 1994. Milenial disebut juga sebagai Echo Boomers karena adanya peningkatan besar tingkat kelahiran pada tahun 1980-an dan 1990-an.

Generasi Milenial lahir pada saat TV berwarna, handphone juga internet sudah ada sehingga generasi ini umumnya ditandai oleh peningkatan penggunaan dan keakraban dengan komunikasi, media, dan teknologi digital. Hal ini mempengaruhi cara pandang generasi Milenial terhadap dunia dengan membuka peluang bagi seseorang untuk mengetahui serta berinteraksi dengan kejadian atau orang-orang dari belahan dunia lain sehingga generasi ini menjadi generasi yang selalu terhubung dengan dunia.

Saat ini memuncaknya angka generasi Milenial membawa perubahan pada masyarakat dan arsitektur. Dalam hal arsitektur, perilaku Milenial membentuk respon dalam perubahan model dan munculnya tipe baru.

\section{Pengertian Apartment}

Apartemen adalah kamar atau beberapa kamar (ruangan) yang diperuntukkan sebagai tempat tinggal, terdapat di dalam sebuah bangunan yang biasanya mampunyai kamar-kamar atau ruangan-ruangan lain semacam itu.

(Kamus Umum Bahasa Indonesia, WJS Poerwadarminta)

\section{Jenis-jenis Apartemen}

a) Tujuan Pembangunannya

- Sosial, biasanya didirikan oleh pemerintah dengan tujuan sosial.

- Pendidikan dan Pelengkap, biasanya apartemen ini didirikan oleh suatu instansi untuk karyawannya atau oleh Perguaian Tinggi untuk pondokan bagi mahasiswanya.

- Komersial, apartemen ini didirikan dengan tujuan mencari keuntungan.

(Yustinaningsih, D. 1988)

b) Golongan Kelas

- Apartemen Mewah: Diperuntukkan golongan atas. Fasilitas yang tersedia setara dengan hotel bintang tia keatas.

- Apartemen Menengah: Diperuntukkan bagi golongan ekonomi menengah. Fasilitas yang tersedia cukup memadai, tetapi tidak terlalu mewah.

- Apartemen Murah: Diperuntukkan bagi golongan ekonomi lemah, fasilitas yang disediakan sangat sederhana.

c) Sistem Kepemilikan

- Rental (Sewa), penghuni membayar uang sewa secara periodik sesuai dengan perjanjian terlebih dulu.

- Kooperatif (Jual - beli), penghuni membeli unit hunian dengan cara menjadi anggota koperasi. 
- Kondominiiim ( Sewa - beli ), pada sistim ini uang sewa berfungsi sebagai uang angsuran pembelian unit hunian.Apabila uang sewa secara keseluruhan sudah memenuhi harga jual, maka unit hunian akan menjadi milik penghuni. (Paul, Samuel, 1967: 39)

- Strata Tittle (Hak milik), penghuni langsung membeli unit hunian seperti pembelian aimah tinggal pada umumnya.

d) Sistem Pelayanannya

- Service Apartement, yaitu tipe apartemen yang selain menyediakan sarana huniannya juga dilengkapi dengan jasa pelayanan yang mengutamakan keamanan, privacy dan pemeliharaan unit-unit hunian yang terjamin.

- Odinary Apartment, yaitu tipe apartemen yang hanya menyediakan sarana hunian saja. Pelayanan hanya terbatas pada pemeliharaan bangunan secara teknis.

- Hotel Apartment, tipe ini merupakan pengembangan dari hotel. Pelayanannya seperti hotel berbintang, seperti: pembersihan unit hunian, pengiriman surat ke unit hunian dan lainlain. (Veracio, L. 1991 : 73)

e) Ketinggian Bangunan

- Low Rise (Bertingkat rendah): Suatu tipe bangunan apartemen bertingkat (multiple dwelling) dengan ketinggian sampai dengan 6 lantai. Sirkulasi vertikal dilengkapi dengan tangga/elevator.

- Medium Rise (Bertingkat sedang): Suatu tipe bangunan apartemen bertingkat dengan ketinggian 6-9 lantai. Sirkulasi menggunakan lift/elevator.

- High Rise (Bertingkat tinggi): Suatu tipe bangunan apartemen bertingkat dengan ketinggian diatas 9 lantai dan dilengkapi dengan lift sebagai alat transportasi vertikal.

f) Bentuk/Massa Bangunan

- Point Block/Tower

Bangunan dengan jumlah lantai sedang sampai tinggi dengan jalur sirkulasi terletak di pusat massa bangunan.

- Slab Block: Bangunan dengan jumlah lantai rendah sampai sedang dengan jalur sirkulasi berada di tengah-tengah antara jajaran unit-unit hunian dan jalur sirkulasi itu erupa lorong/koridor.

- Variant: Bangunan dengan perpaduan antara point block/tower dan slab.

g) Sistem Penyusunan Lantai

- Simplex (One level): Suatu unit hunian, dilayani dalam satu lantai dan setiap lantai terdiri dari beberapa unit hunian.

- Duplex (Two level): Kebutuhan satu unit hunian dilayani dalam 2 lantai.

- Triplex (Three level): Kebutuhan satu unit hunian dilayani dalam 3 lanai dan pintu masuk apartemen setiap 3 lantai.

\section{Smart Living}

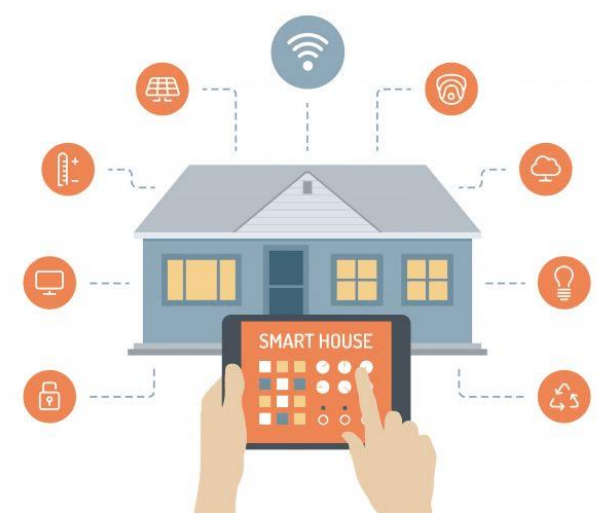

Gambar 1 Smart Living

Sumber : https://telset.id/152770/apa-saja-perangkat-penting-di-layanan-smart-living 
Konsep Smart Living menawarkan kemudahan untuk memantau dan mengatur tempat tinggal melalui perangkat mobile dimanapun dan kapanpun. Melalui perangkat mobile, pemilik hunian dapat memantau CCTV, Sistem penguncian hunian, menyalakan atau mematikan listrik dan mengatur AC. Perangkat pertama yang diperlukan adalah perangkat yang paling penting karena Home Gateway merupakan alat yang menghubungkan seluruh perangkat Smart Living yang terkoneksi dengan modem Pengguna.

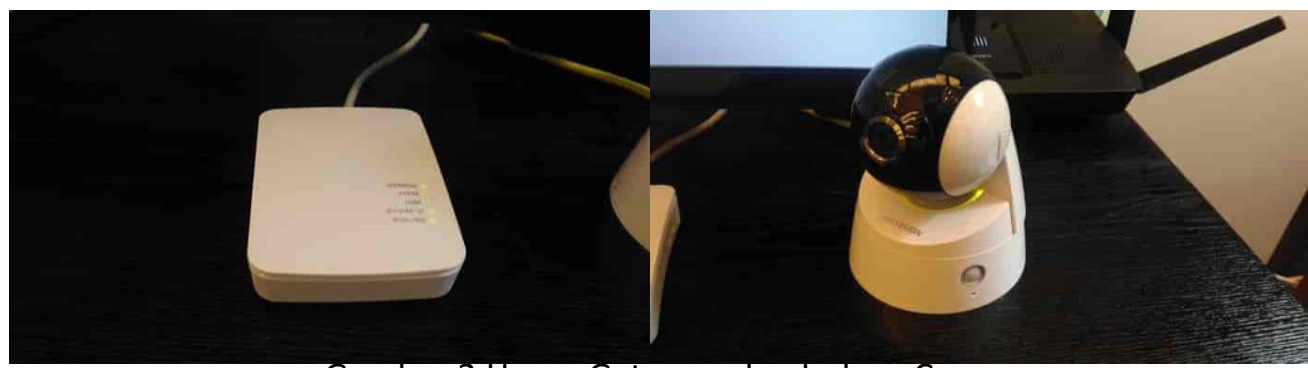

Gambar 2 Home Gateway dan Indoor Camera

Sumber : https://telset.id/152770/apa-saja-perangkat-penting-di-layanan-smart-living

Selanjutnya adalah indoor camera yang berguna untuk keamanan di dalam rumah pelanggan. Hebatnya, alat tersebut mampu bergerak ke berbagai arah yakni atas dan bawah serta kiri dan kanan. Indoor camera juga mampu mendeteksi gerakan dari motion sensor yang disematkan di dalamnya sehingga bila ada sesuatu yang tidak diinginkan, maka pengguna akan mendapatkan notifikasi lewat smartphone secara langsung.

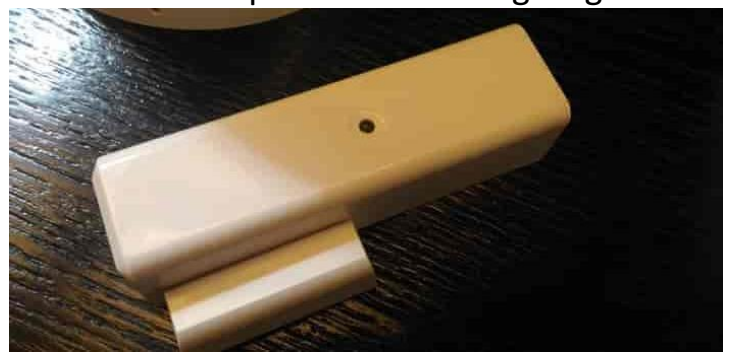

Gambar 3. Door Sensor

Sumber : https://telset.id/152770/apa-saja-perangkat-penting-di-layanan-smart-living

Door/Windows Sensor yang memiliki kemampuan untuk mendeteksi setiap gerakan pintu atau jendela rumah ketika dibuka atau ditutup. Perangkat ini bisa mengirim sinyal langsung ke Wireless Siren \& Strobe Alarm jika mendapatkan hal-hal yang tidak diinginkan. Wirelless Siren and Strobe alarm digunakan untuk melindungi rumah penggunanya dari hal-hal yang tidak diinginkan lewat alarm yang menyala lumayan keras. Alat ini akan mengeluarkan suara sirene yang cukup keras disertai lampu alarm yang menyala jika mendapatkan sinyal tanda bahaya.

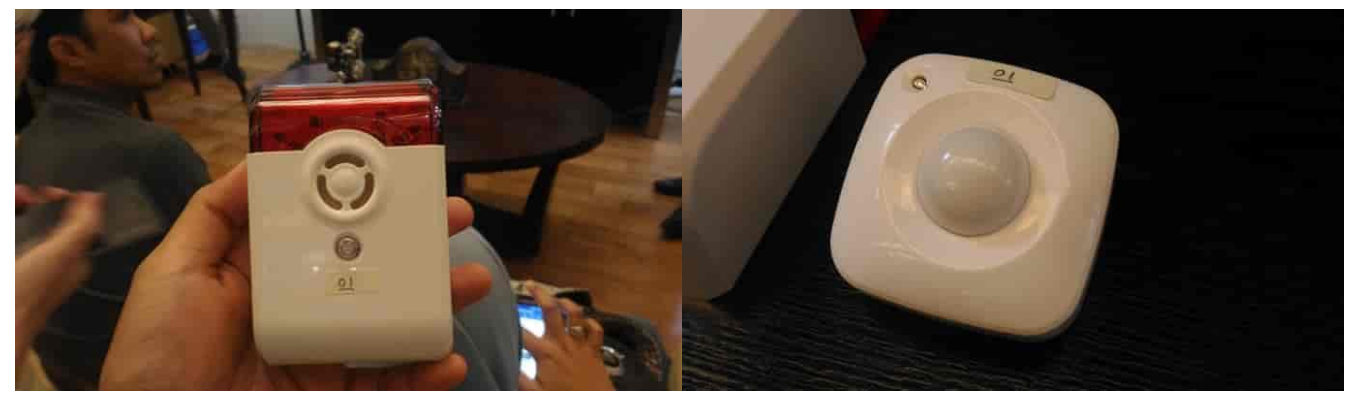

Gambar 4 Wirelless Siren dan Motion Sensor

Sumber : https://telset.id/152770/apa-saja-perangkat-penting-di-layanan-smart-living 
Kemudian juga digunakan perangkat 4 in 1 Motion Sensor yang bertugas untuk mengatur lampu, AC dan lainnya karena memiliki kemampuan untuk memantau gerakan, suhu ruangan, kelembapan dan pencahayaan.

\section{METODE}

Metode yang digunakan dalam mencapai tujuan ini adalah metode penelitian kualitatif yang terdiri dari tahap pengumpulan data, pengolahan data, pembahasan, dan kesimpulan. Pengumpulan data dilakukan dengan cara observasi atau tinjauan langsung ke lapangan dan studi dokumen. Dalam Menentukan Tapak yang akan dipilih, dilakukan penelitian terhadap presentase jumlah Milenial di Jakarta dan dibandingkan dengan jumlah Penduduk Jakarta di setiap kabupaten.

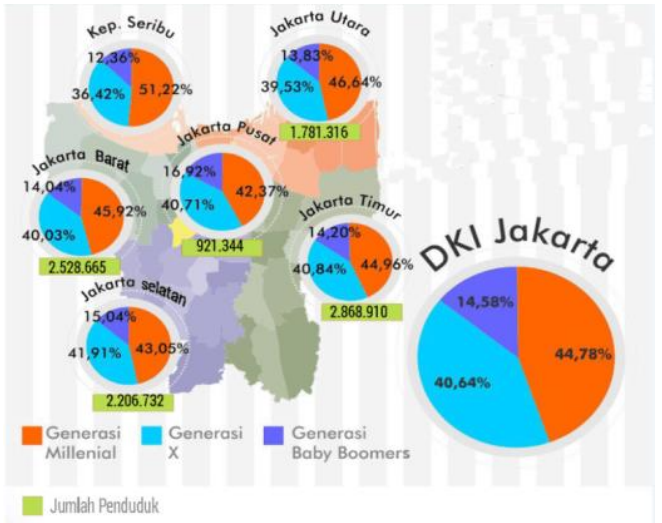

Gambar 5 Presentase Generasi Sumber : tirto.id

Berdasarkan perbandingan presentase dan jumlah penduduk Generasi Milenial terhadap generasi $X$ dan Generasi Baby Boomers di Jakarta. Maka didapatkan lokasi dengan jumlah Generasi Milenial terbanyak berada di Jakarta Timur sehingga Jakarta Timur dipilih sebagai lokasi tapak. Lalu dalam menentukan kapasitas dan jenis unit yang akan dirancang ditentukan berdasarkan usia generasi Milenial yang lahir pada tahun 1981-1994 yang berarti memiliki umur 24 - 37 tahun. Berdasarkan rentang umur generasi Milenial yang berada di usia produktif dan berencana untuk berkeluarga maupun sudah berkeluarga, maka Jenis unit aparment yang dibuat adalah tipe studio yang dapat digunakan untuk milenial yang belum berkeluarga dan tipe 2 bedroom untuk Milenial yang sudah berkeluarga. Dan di kelurahan tapak yang dipilih terdapat 2.649 penduduk dengan usia Milenial, sehingga sebagian jumlah tersebut dapat ditampung di Apartment Sewa Smart Living yang akan di rancang.

Tabel 1. Jumlah Peduduk

\begin{tabular}{|c|l||l|l||l|l||c|}
\hline Tahun & Provinsi & Nama_Kabupaten & Nama_Kecamatan & Nama_Kelurahar & Usia & Jumlah \\
\hline \hline 2017 & DKI Jakarta & JAKARTA TIMUR & JATINEGARA & BALI MESTER & $0-4$ & 562 \\
\hline 2017 & DKI Jakarta & JAKARTA TIMUR & JATINEGARA & BALI MESTER & 59 & 814 \\
\hline 2017 & DKI Jakarta & JAKARTA TIMUR & JATINEGARA & BALI MESTER & 1014 & 760 \\
\hline 2017 & DKI Jakarta & JAKARTA TIMUR & JATINEGARA & BALI MESTER & $15-19$ & 801 \\
\hline 2017 & DKI Jakarta & JAKARTA TIMUR & JATINEGARA & BALI MESTER & $20-24$ & 863 \\
\hline 2017 & DKI Jakarta & JAKARTA TIMUR & JATINEGARA & BALI MESTER & $25-29$ & 847 \\
\hline 2017 & DKI Jakarta & JAKARTA TIMUR & JATINEGARA & BALI MESTER & $30-34$ & 846 \\
\hline 2017 & DKI Jakarta & JAKARTA TIMUR & JATINEGARA & BALI MESTER & $35-39$ & 956 \\
\hline 2017 & DKI Jakarta & JAKARTA TIMUR & JATINEGARA & BALI MESTER & $40-44$ & 881 \\
\hline 2017 & DKI Jakarta & JAKARTA TIMUR & JATINEGARA & BALI MESTER & $45-49$ & 896 \\
\hline 2017 & DKI Jakarta & JAKARTA TIMUR & JATINEGARA & BALI MESTER & $50-54$ & 901 \\
\hline 2017 & DKI Jakarta & JAKARTA TIMUR & JATINEGARA & BALI MESTER & $55-59$ & 709 \\
\hline 2017 & DKI Jakarta & JAKARTA TIMUR & JATINEGARA & BALI MESTER & $60-64$ & 562 \\
\hline 2017 & DKI Jakarta & JAKARTA TIMUR & JATINEGARA & BALI MESTER & $65-69$ & 402 \\
\hline 2017 & DKI Jakarta & JAKARTA TIMUR & JATINEGARA & BALI MESTER & $70-75$ & 265 \\
\hline 2017 & DKI Jakarta & JAKARTA TIMUR & JATINEGARA & BALI MESTER & $>75$ & 223 \\
\hline
\end{tabular}

Sumber : Data Penduduk DKI Jakarta 


\section{DISKUSI DAN HASIL}

Program Arsitektural utama yang ditawarkan adalah apartment milik dengan pertimbangan sebagai berikut :

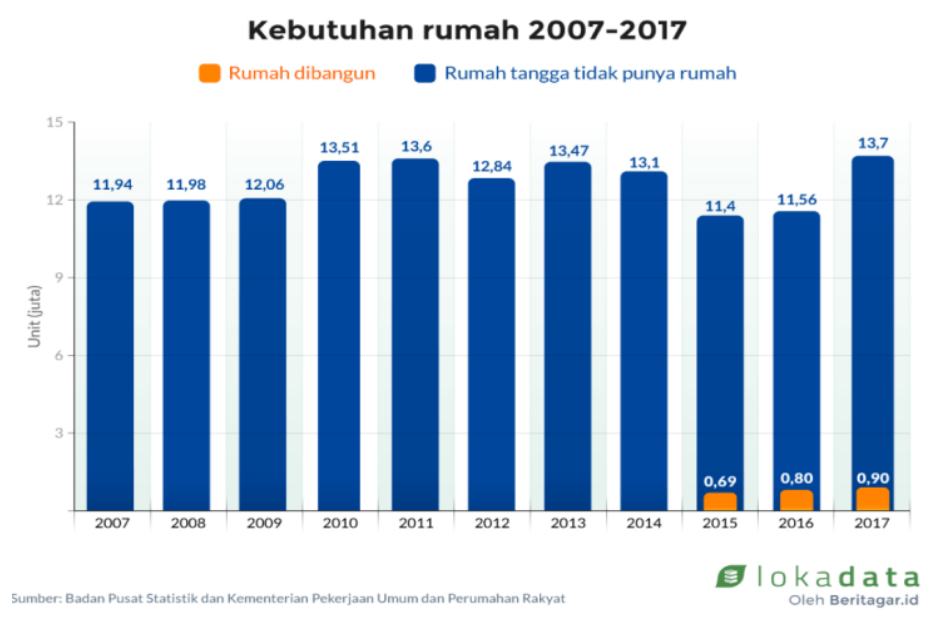

Gambar 6. Kebutuhan Rumah

Sumber : Badan Pusat Statistik dan Kementrian pekerjaan umum dan perumahan rakyat

Berdasarkan tabel perbandingan antara kebutuhan rumah dengan jumlah rumah yang terbangun, jumlah rumah yang terbangun belum memenuhi kebutuhan rumah. Sehingga perlu dibangun hunian dengan ketersediaan lahan yang terbatas yaitu dengan membangun Apartment atau rumah susun. Generasi Milenial memiliki Gaya hidup yang serba praktis, membuat para Milenial lebih memilih untuk tinggal di apartemen yang berkualitas dengan berbagai kemudahan akses dan kelengkapan fasilitas.

Berada di pusat kota membuat akses terhadap kebutuhan seperti kantor, fasilitas umum, pusat hiburan menjadi cepat dan ukuran Apartment yang tidak terlalu besar dibanding rumah merupakan alasan mengapa Milenial lebih memilih apartement. Generasi Milenial cenderung memanfaatkan waktu untuk bekerja. Sehingga dengan ukuran minimalis, akan mempersingkat waktu membersihkan dan merawat tempat tinggalnya.

\section{CENTRE FOR}

\section{Kegiatan yang paling menarik minat}

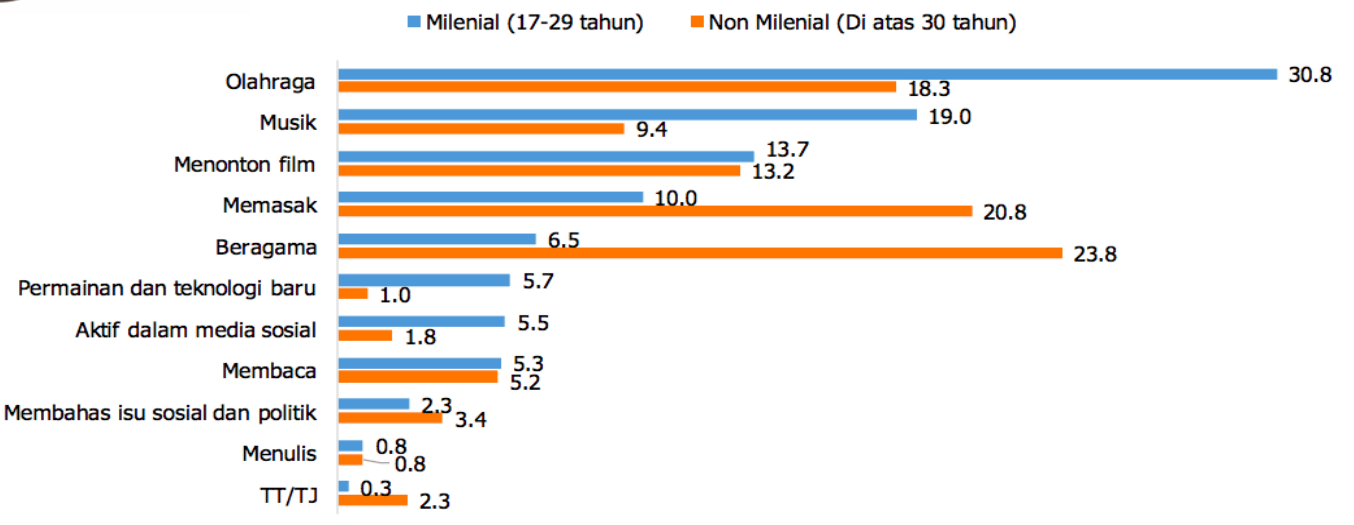

Terdapat perbedaan kegiatan yang menarik antara milenial dan non-milenial. Milenial tertarik dengan olahraga dan non milenial dengan kegiatan agama

Gambar 7. Kegiatan Favorit Millenial Sumber : Centre for Strategic and International Studies 
Menurut survei Centre For Strategic and International Studies menunjukan bahwa generasi millenial memiliki minat paling besar terhadap olahraga. Maka fasilitas apartment difokuskan terhadap fasilitas olahraga yang diminati oleh generasi Milennial.

Olahraga Favorit Generasi Milenial dan Generasi Z (10 Cabang )
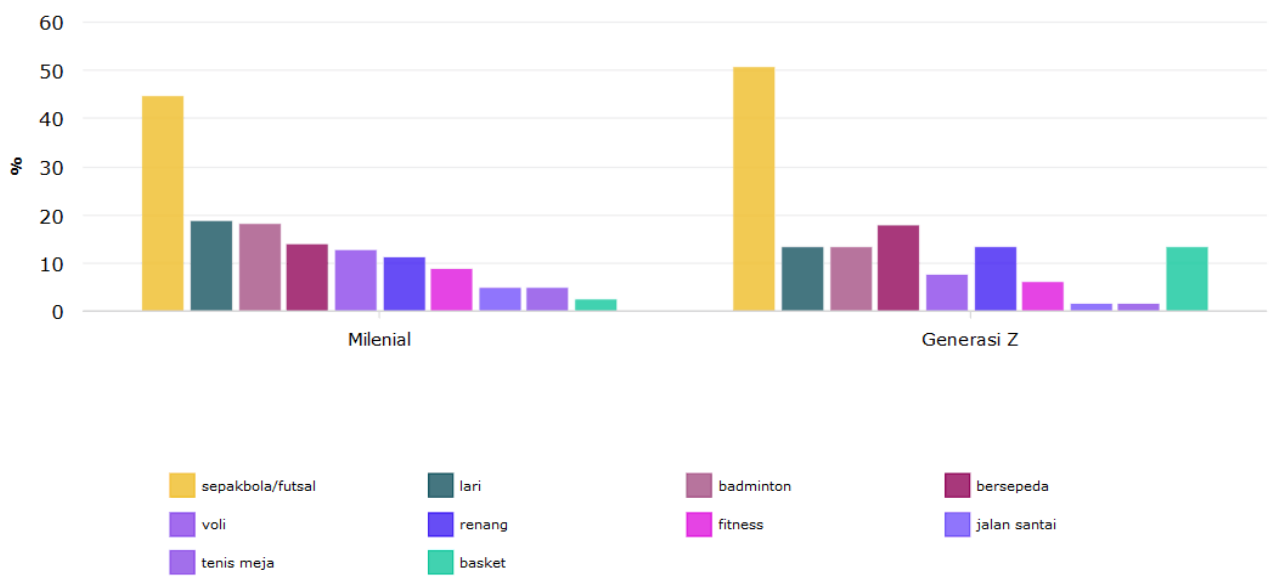

Gambar 8. Olahraga Favorit Millenial

Sumber : Centre for Strategic and International Studies

Dalam menentukan fasilitas olahraga apa yang akan diprogram dalam perancangan apartment, maka diperlukan data olahraga favorit generasi milleniall. Menurut Alvara Research Center tahun 2018,terdapat 10 olahraga yang menjadi favorit generasi Milenial dan urutan pertama adalah sepakbola atau futsal. Sehingga fasilitas olahraga yang ada diapartment adalah lapangan Futsal dengan fasilitas -fasilitas olahraga lainnya seperti jogging track, kolam renang dan fitness centre.

Generasi Milenial lahir antara tahun 1981 - 1994 sehingga generasi ini sekarang berada di usia produktif yaitu 25 - 38 tahun sehingga Tipe Hunian pada apartment yang direncanakan adalah studio dan 2 bedroom yang diperuntukan untuk penghuni belum menikah yang bekerja dan pasangan muda yang baru berkeluarga.

Berdasarkan Karakteristik Generasi Milenial yang berinteraksi dengan teknologi secara intens dan menggunakannya secara terintegrasi selama masa hidupnya maka Apartment dirancang dengan konsep Smart Living. Konsep smart living memang merupakan paradigma gaya hidup yang mengutamakan kecermatan, kepraktisan, dan kreativitas yang sesuai dengan karakteristik Milenial yang juga menyukai hal yang praktis dan efisien. Selain penggunaan teknologi, penggunaan Perabotan Multifungsi juga membuat desain ruang menjadi lebih efisien. Dengan penggunaan Murphy bed yang dapat dialih fungsikan menjadi meja kerja dan meja ruang tamu yang dapat gunakan sebagai meja makan,

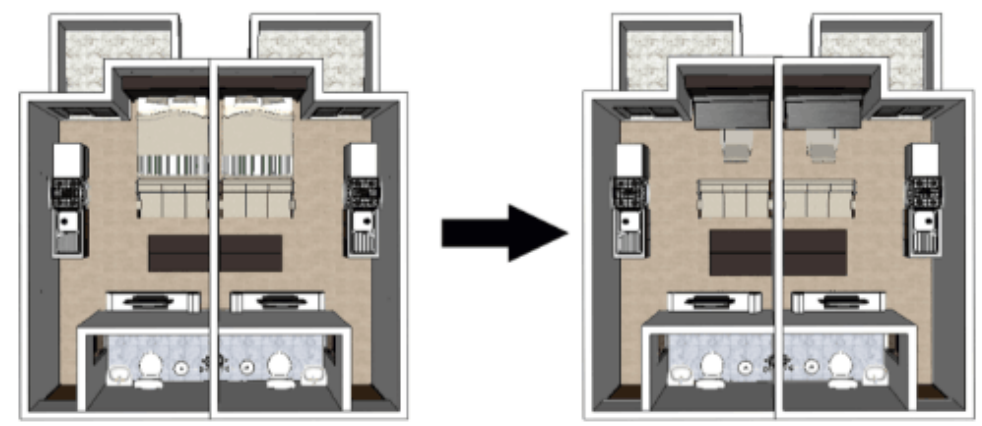

Gambar 9. Unit Studio

Sumber : Penulis, 2019 
Hunian dengan konsep Smart Living menawarkan kemudahan untuk memantau dan mengatur tempat tinggal melalui perangkat mobile dimanapun dan kapanpun. Melalui perangkat mobile, pemilik hunian dapat memantau CCTV, Sistem penguncian hunian, menyalakan atau mematikan listrik dan mengatur AC.

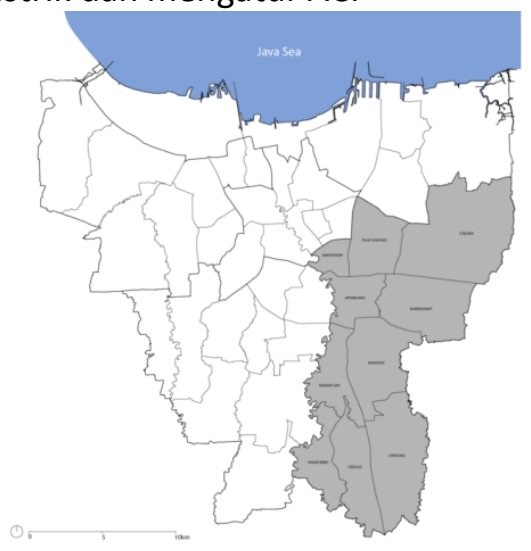

Gambar 10. Peta Jakarta Timur

Sumber : https://id.wikipedia.org/wiki/Templat:Location_map_Jakarta

Lokasi tapak berada di Jakarta Timur dengan pertimbangan bahwa Apartment untuk generasi Milenial sebaiknya berada di pusat kota karena generasi Milenial memiliki mobilitas yang tinggi dan lebih suka tinggal di pusat kota.

\section{Data Lokasi}

Alamat: Jalan Matraman Raya, Jakarta Timur

KDB : $55 \%$

$\mathrm{KLB}: 3$

$\mathrm{KB}:: 8$

$\mathrm{KDH}: 30$

KTB : 55

Luas Tapak: $10.000 \mathrm{~m}^{2}$

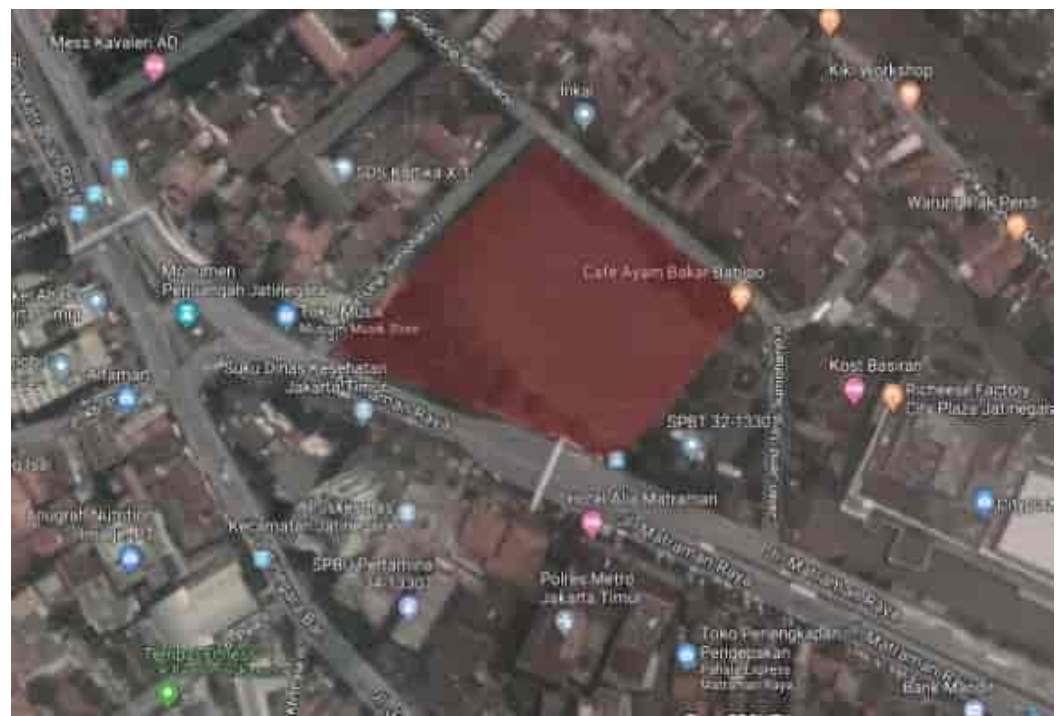

Gambar 11. Peta Lokasi Tapak Sumber : https://www.google.com/maps 
Tapak merupakan lahan kosong yang berada di jalan Matraman Raya yang merupakan jalan arteri sedangkan di sebelah Timur terdapat jalan Jend. Urip Sumoharjo II dan di sebeah Barat terdapat jalan Jend. Urip Sumoharjo I yang merupakan jalan kolektor.

Terdapat halte Busway di dekat tapak dengan jarak $100 \mathrm{~m}$ sehingga dapat dilakukan penerapan perancangan berbasis TOD sehingga dapat memaksimalkan penggunaan angkutan massal seperti busway. Di area tapak juga teradapat halte bus namun sudah rusak sehingga perlu adanya perbaikan. Dalam jarak $100 \mathrm{~m}$ terdapat Mall Ramayana yang dapat menjadi tempat hiburan bagi Generasi Milenial.

Batas Area Lahan tapak antara lain:

Utara : Jalan Jend. Urip Sumoharjo II

Timur : Jalan Jend. Urip Sumoharjo II

Barat : Jalan Jend. Urip Sumoharjo I

Selatan : Jalan Kramat Raya

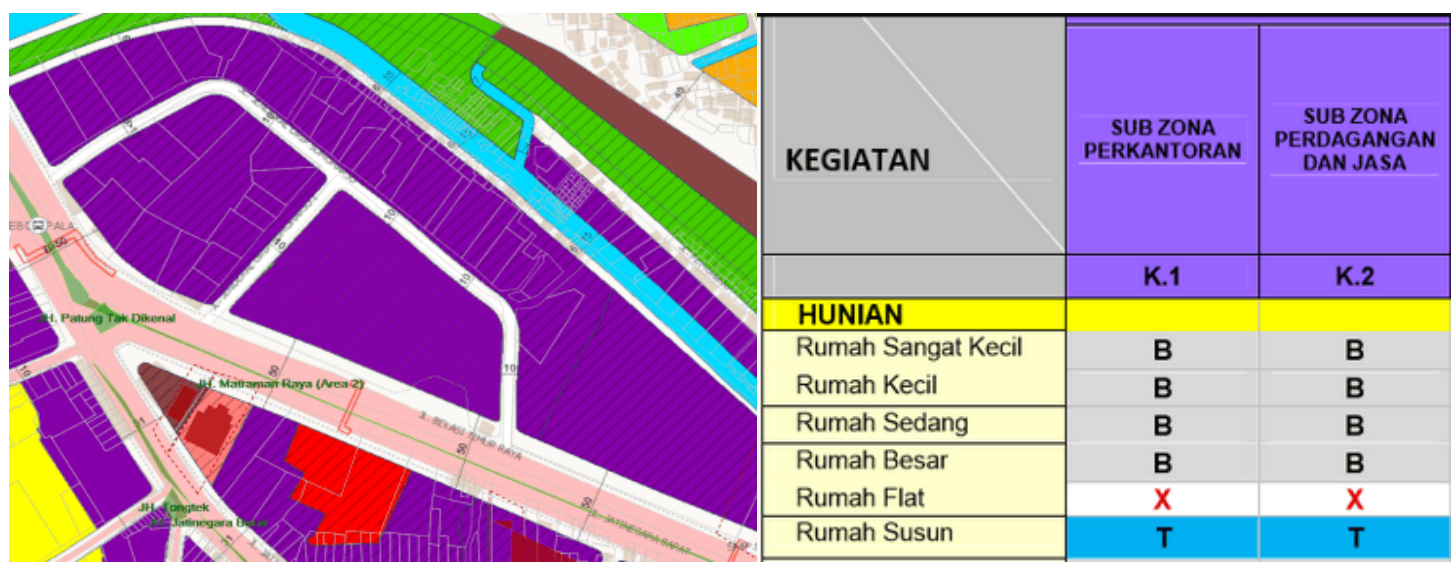

Gambar 12. Peta Zonasi Tapak

Sumber : https https://tataruang.jakarta.go.id

Tapak berada di zona perkantoran dimana menurut ITBX untuk pembangunan rumah susun atau apartment diizinkan terbatas.

Tabel 2. Kelebihan Tapak

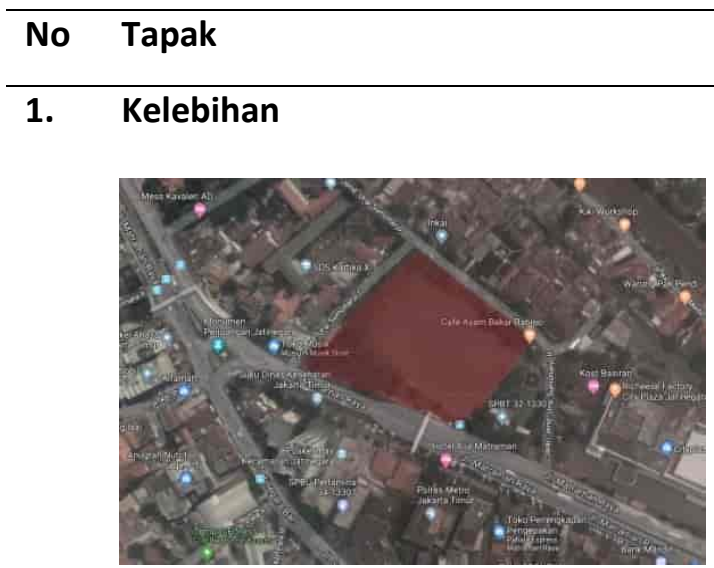

\section{Keterangan}

-Berada di jalan arteri yang menghubungkan pusat kota dengan daerah sekitarnya.

-Dekat dengan Halte Busway

-Terdapat Halte Bus

-jalan cukup lebar

-Memiliki jalan kolektor disekitar tapak

-Luas lahan cukup besar

-Dekat dengan Mall Ramayana

Sumber : Penulis, 2019 
Tabel 3. Analisa Tapak

\begin{tabular}{ll}
\hline ANALISA & KETERANGAN \\
\hline Aksesibilitas & $\begin{array}{l}\text { Di bagian selatan tapak berada di depan } \\
\text { jalan Matraman Raya yang merupakan } \\
\text { jalan Arteri sehingga entrance dapat } \\
\text { diletakan di area selatan tapak untuk } \\
\text { mempermudah akses. Tapak dikelilingi } \\
\text { oleh jalan kolektor yang dapat } \\
\text { dimanfatkan untuk area masuk servis. }\end{array}$ \\
\hline Kebisingan & $\begin{array}{l}\text { Area selatan tapak yang merupakan } \\
\text { jalan Arteri memiliki tingkat kebisingan } \\
\text { yang tinggi akibat banyaknya kendaraan } \\
\text { yang melintas. Sedangkan area lainya } \\
\text { memiliki tingkat kebisingan rendah } \\
\text { karena jalan kolektor memiliki intensitas } \\
\text { kendaraan yang lebih sedikit dan lebih } \\
\text { lambat. Maka area hunian perlu } \\
\text { diletakan di belakang sehingga jauh dari } \\
\text { kebisingan tinggi. }\end{array}$ \\
\hline
\end{tabular}

\section{Arah Matahari}

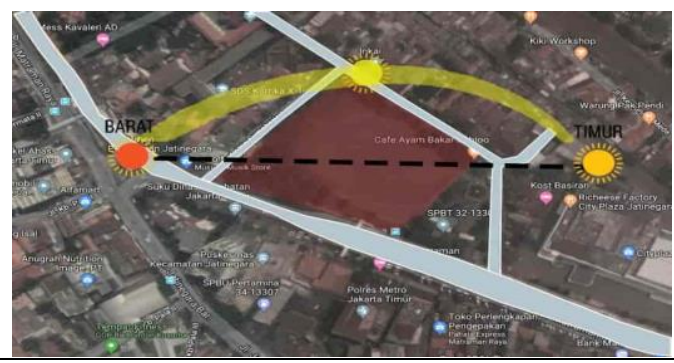

\section{Zoning}
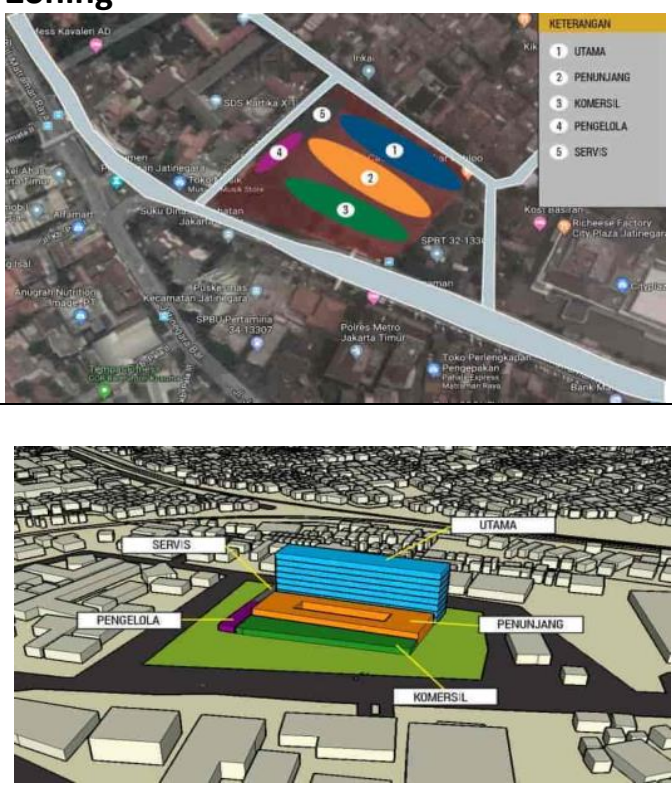

Arah matahari bergerak dari timur ke barat.

Orientasi bangunan dibuat menghadap ke selatan dan utara untuk menghindari panas matahari langsung.

Sumber: Penulis, 2019 


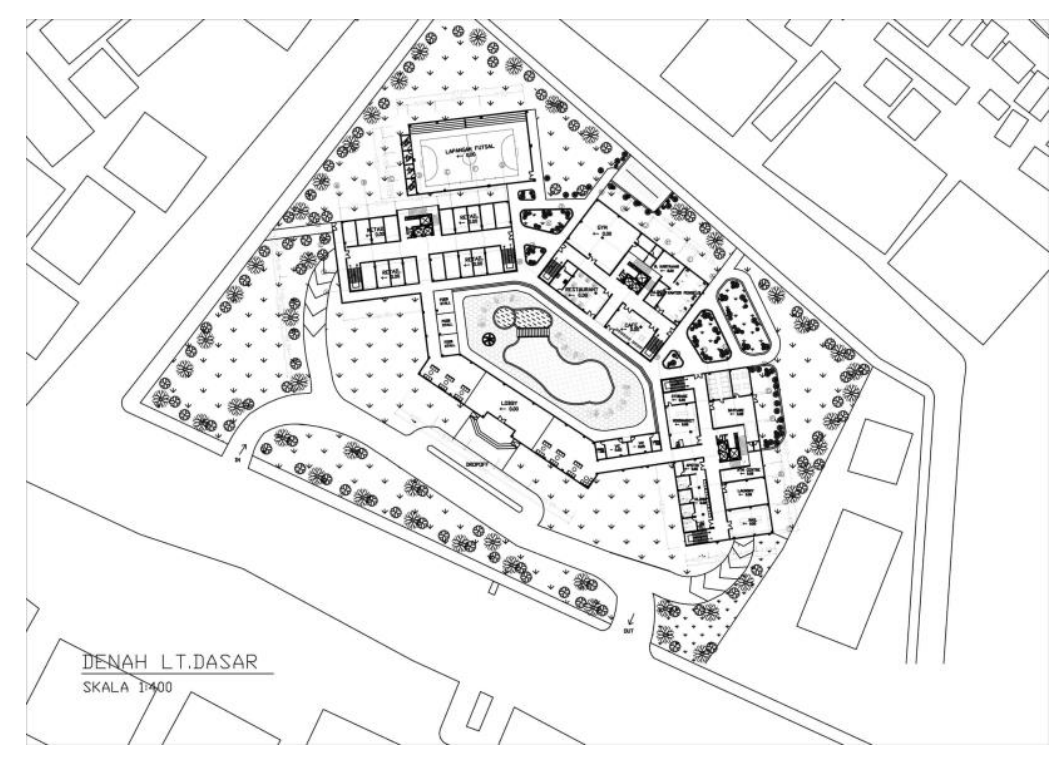

Gambar 13. Denah Lt Dasar

Sumber: Penulis, 2019

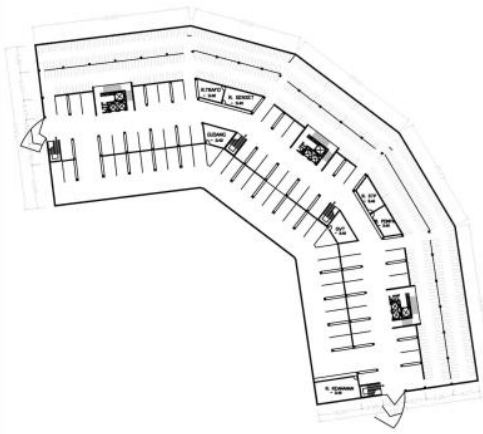

DENAH LT BASEMENT

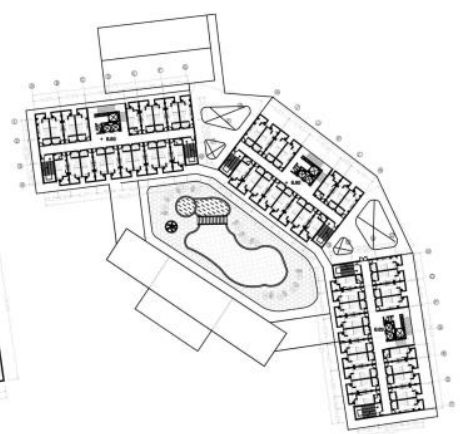

DENAH LT.

Gambar 14. Denah Basement dan Lantai 2

Sumber: Penulis, 2019

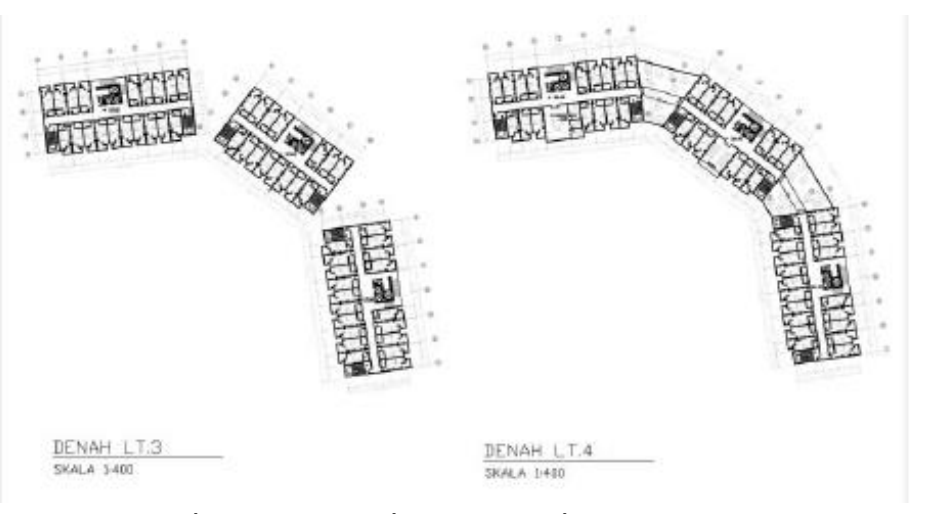

Gambar 15. Denah Lantai 3 dan Lantai 4

Sumber: Penulis, 2019 


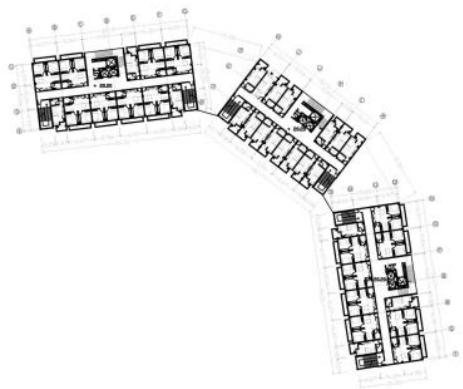

$\frac{\text { DENAH LT.5 }}{\text { SKALA } 1: 400}$

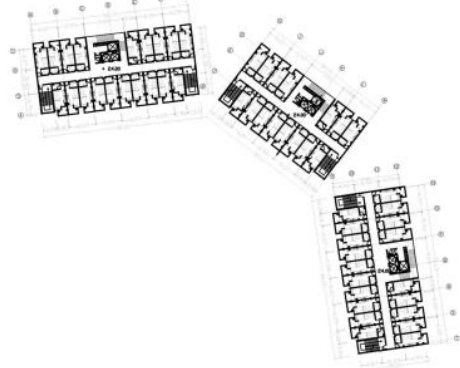

$\frac{\text { DENAH LT.6-7 }}{\text { SKALA } 1400}$

Gambar 16. Denah Lantai 5 dan 6-7

Sumber: Penulis, 2019

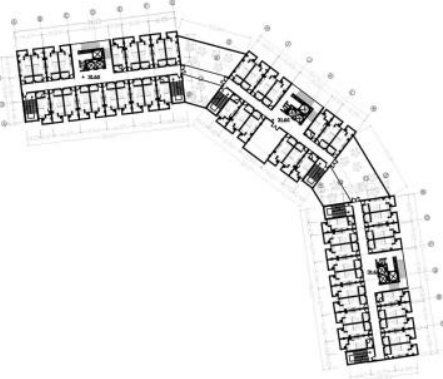

$\frac{\text { DENAH LT } 8}{\text { SKALA } 11400}$

Gambar 17. Denah Lantai 8 dan Roof Top

Sumber: Penulis, 2019

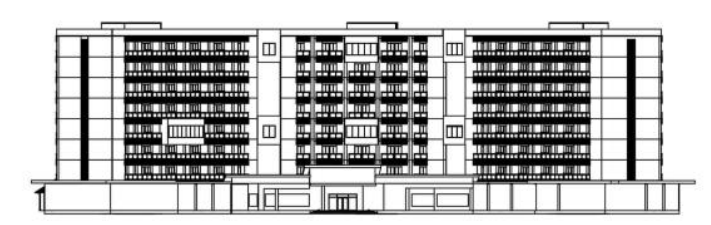

TAMPAK MUKA SKALA $1: 400$

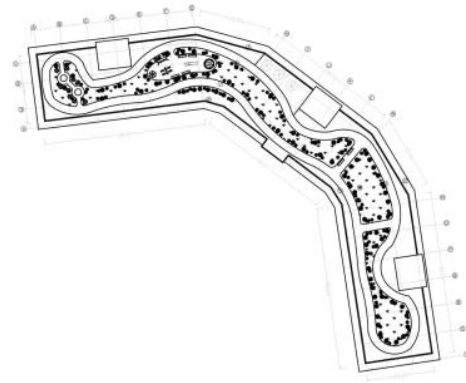

DENAH RDDFTIP

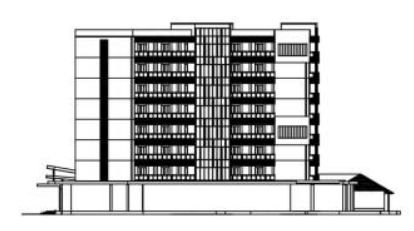

TAMPAK SAMPING KANAN SKALA 11400

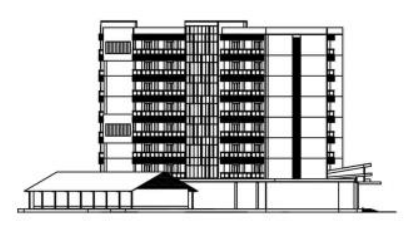

TAMPAK SAMPING KIRI

SKALA 1:400

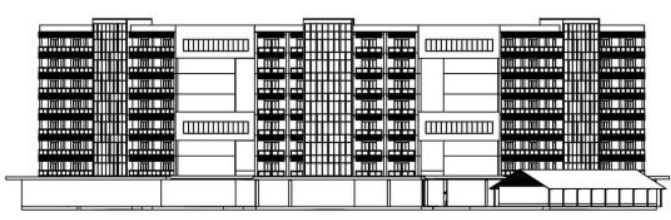

TAMPAK BELAKANG 


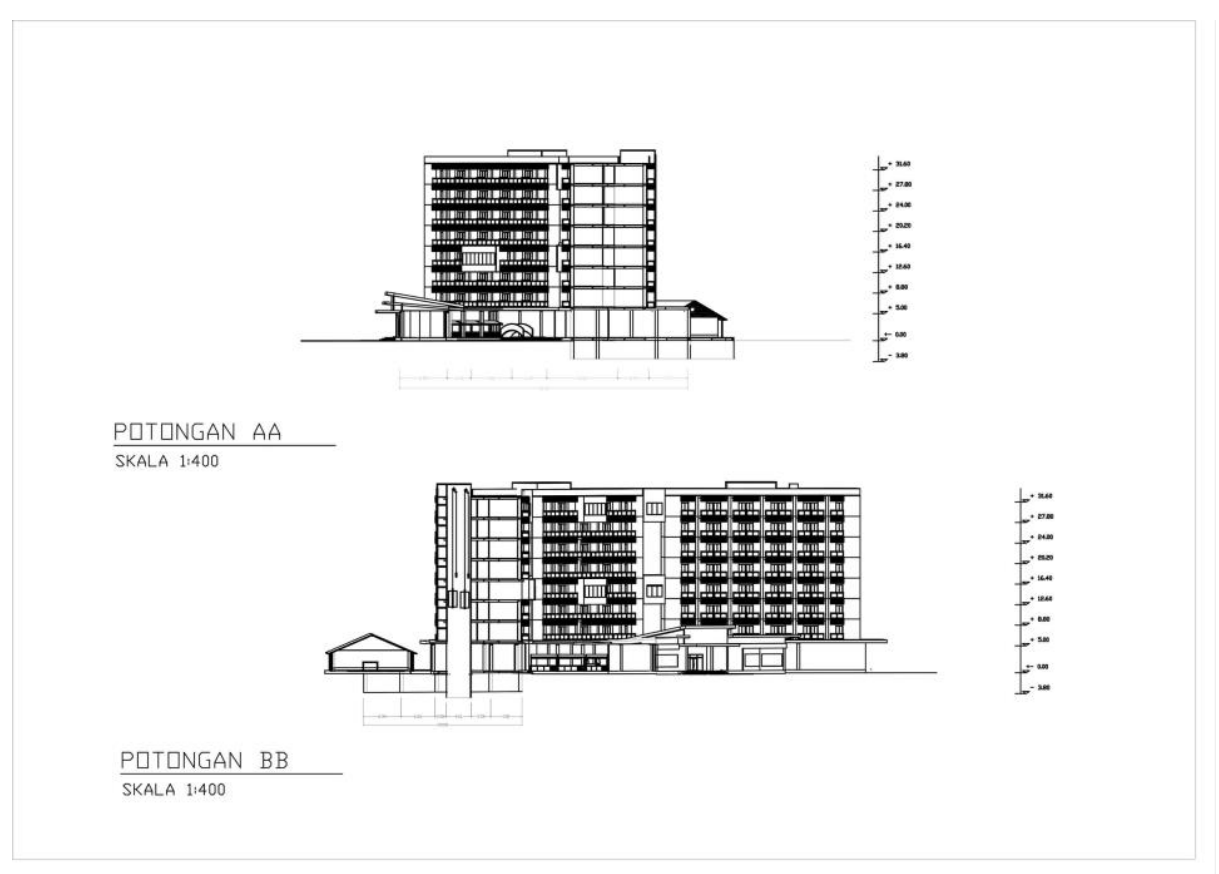

Gambar 19. Potongan Bangunan

Sumber: Penulis, 2019

\section{KESIMPULAN DAN SARAN}

Generasi Milenial merupakan generasi yang smart dekat dengan teknologi semasa hidupnya dan dapat memanfaatkanya untuk memberikan kemudahan dalam melakukan aktivitas dan memenuhi kebutuhan mereka.

Dalam hal desain Apartment Smart Living, unit hunian disesuaikan dengan sifat generasi Milenial yang menyukai teknologi, hal simpel dan efisien sehingga desain Smart Living yang dirancang membuat penghuninya dapat mengatur CCTV, listrik, kunci dan AC melalui Smartphone mereka dan juga pemanfaatan ruang yang efisien dengan menggunakan perabotan multifungsi dalam unit hunian. Lalu fasilitas yang berada di apartment juga dibuat berdasarkan data mengenai perilaku Milenial.

Sebagai saran, seiring dengan adanya Apartment Smart Living yang telah dibuat untuk mewadahi kebutuhan Milenial diperlukan adanya pembangunan fasilitas - fasilitas umum yang smart oleh Pemerintah sehingga dapat menjadi terbentuk Smart City.

\section{REFERENSI}

Neufert, E. (2002). Data Arsitek (Jilid 1). Jakarta: Erlangga.

Panero, J. (2003). Dimensi Manusia dan Ruang. Jakarta : Erlangga

Paul, S. $\quad$ (1967). Apartments: Their Design and Development. 39-47. Amsterdam.

Poerbo, H. (1995). Utilitas Bangunan. (Edisi Revisi) Cetakan Kedua. Jakarta : Djambatan

https://www.academia.edu/36159155/Arsitektur_dan_Perilaku_Manusia_Kajian_Arsitektur_ pada_B idang_Perpustakaan_ (diakses 15 Januari 2019)

https://www.scribd.com/doc/284966721/Arsitektur-Perilaku (diakses 15 Januari 2019)

https://madzhabarsitektur.wordpress.com/2015/09/03/pendekatan-prilaku-dalamarsitektur/ (diakses 15 Januari 2019)

https://www.ilmu-ekonomi-id.com/2016/10/pengertian-dan-tujuan-sdgs-sustainabledevelopment- goals.html (diakses 15 Januari 2019)

https://properti.kompas.com/read/2017/09/05/185511621/fakta-bicara-milenial-ternyatalebih- senang-hidup-di-apartemen (diakses 15 Januari 2019) 
https://finance.detik.com/properti/d-3776400/milenial-pilih-apartemen-ketimbang-rumahtapak- karena-gaya-hidup (diakses 15 Januari 2019)

https://economy.okezone.com/read/2018/08/19/470/1938562/alasan-apartemen-cocokjadi- hunian-pertama-milenial (diakses 15 Januari 2019)

https://www.lamudi.co.id/journal/begini-ciri-rumah-idaman-generasi-milenial/ (diakses 15 Januari 2019)

http://e-journal.uajy.ac.id/11435/3/TA140502.pdf (diakses 23 Januari 2019) 